\title{
Teaching writing by using Visual, Auditory, Read/Write, And Kinesthetic (VARK) learning style in descriptive text to the seventh grade students of SMPN 2 Jiwan
}

\author{
Ilham Nugroho Hanurawan \\ Universitas PGRI Madiun, Indonesia \\ ilham.schitzoo@gmail.com
}

\begin{abstract}
Writing is one of the English skills. Teaching writing is a process to improve students' ability to write in English correctly. Descriptive text is text used to describe a person, place or object. The difficulty experienced in teaching writing through descriptive text is the lack of attention of students towards the explanation given by the teacher. To overcome this, researchers applied VARK learning style to teaching writing. VARK learning style is a learning style using all five senses to get information or knowledge in the teaching and learning process. This study aims to explain the application of VARK learning style in teaching writing through descriptive text. The procedures for applying VARK learning style in teaching writing through descriptive text are: (1) The teacher explains the meaning, patterns and characteristics of descriptive text languages, (2) The teacher asks students to make small groups, (3) The teacher gives examples of descriptive texts, (4) The teacher gives questions in the form of pictures to students and asks to make descriptive texts, (5) The teacher asks students to show the results of students' work in front of the class. Based on this research, it can be seen that the advantages of VARK learning style is that it can increase student learning interest, student enthusiasm and reciprocity between teacher and students.
\end{abstract}

Keywords: teaching writing; descriptive text; VARK Learning Style

\section{INTRODUCTION}

Writing is one of all basic skills in English material. It is important skill in English. In a school, the student gets the writing materials by teaching writing. Teaching writing is a way that the teacher uses to teach the students how to write in correct way. According to Nunan (in Erlik Widyani and Nuri Ati, 2012: 45),"Writing is the process of thinking to invent ideas, thinking about how to express into a good writing, and arranging the ideas into statement and paragraph clearly." It means that writing is a way to transfers and explores the idea in a written formula. Actually writing skill is a way which used by the people that have difficulties in speaking.

Learning English writing is the process to get knowledge about writing skill in English material. The student received this material from their school. In learning English writing, the students are studied all about aspects in writing skill. By learning English writing, the teacher has an expectation to the student can understand well in writing skill. They can do all activities about writing something by their own words in correct way. Actually, there are some difficulties in teaching writing skill to the student in a school. The general problems are a student gets low attention to the explanation from the teacher and the student is not interesting with the material. This is not so good. To solve this problem, the teacher must find a new way so the students have more attention to material and interesting with the explanation from the teacher. In this case, researcher chooses VARK learning style to solving the problem above.

According to Dunn and Dunn (in Richard and Stephen, 2002: 66) "Defined learning style as the way in which biological and developmental personal characteristics make different methods of teaching appropriate for some students but not for others". It means that learning style is the way that is suitable to the students in biological or developmental personal characteristics. Learning style is one of the ways to transfer the material. So the students not feel bored in teaching learning process. In this 
research the writer will introduce a new learning style that is Visual, Auditory, Read/write, and Kinesthetic (VARK) learning style. VARK is teaching learning process with multi modal. According to Vanessa Marcy (2003: 67), "The VARK inventory (VARK is an acronym for visual, aural, $\mathrm{read} / \mathrm{write}$, and kinesthetic learning modalities) is one such tool that is easy to use and can give students information on how to maximize their learning". It means that VARK is learning style that consists of visual, aural, read/write, and kinesthetic learning modalities that appropriate to give information to the students in teaching learning process.

In this research, the researcher wants to explore writing skill of the students at SMPN 2 Jiwan using suitable learning style that is VARK learning style. Because in that school the teacher still uses old media. So, it makes the students cannot explore writing skill well. A new style was needed by the students to make the class more attractive by using VARK so, it will increase the student basic skills. One of them is writing skill. Based on background above, the researcher formulated the title of the research as "Teaching Writing by Using Visual, Auditory, Read/Write, and Kinesthetic (VARK) Learning Style in Descriptive Text to the Seventh Grade Students of SMPN 2 Jiwan".

\section{METHOD}

Research methodology is a way to systematically solve the research problem. According to Redman and Mory (2004: 1), "A systematized effort to gain new knowledge". It means that research is activities to find specific topic with systematize procedures. In other hand, according to Kothari (2004: 31), "A research design is the arrangement of conditions for collection and analysis of data in a manner that aims to combine relevance to the research purpose with economy in procedure." It means that research design is activity to arrange the data that collect and analyzing data with systematize, so it relevant with the purpose of research.

This research related to the analysis of teaching writing through VARK learning style. It observed how the teachers performed the process of teaching and learning and what activities the students did in the classroom. It also described the subject naturally as what it was. So the research was designed as qualitative research. According to Auerbach and Silverstein (2003: 1), "Qualitative research is research that involves analyzing and interpreting texts and interviews in order to discover meaningful patterns descriptive of a particular phenomenon". It means that qualitative research is the research that contains of analyzing and interpreting texts with the purpose to found the meaning of pattern descriptive of the particular phenomenon.

This research uses descriptive qualitative. According to Creswell (2008: 254)," descriptive qualitative study aims as investigating detail rendering of people, place, and events in a setting in qualitative approach". It means that descriptive qualitative is the research that have purpose to study based on the subject of the research in details. The source data of this research was taken from social situation, participant and document. Technique collecting data in this research are observation, interview and documentation.

\section{FINDING AND DISCUSSION}

After having a research, the researcher presents the description of the data and research findings. The data are taken from the result of the observation, interview, and documentation. There are four aspects that is observed in the implementation of teaching writing by using VARK learning style, consist of; learning activity, class interaction, students' appreciation, and students' development.

Pre-activities are the activities done before teaching learning process started. First, teacher gives a greeting and call the list the students. Than, students replay greeting of teacher . after that, teacher and students pray before start the lesson. The Captain of the class leads the students to pray

\section{8 | English Teaching Journal: A journal of English Literature, Linguistics, and Education}


together. Before the lesson begin, teacher giving motivation to the students. The teacher gives motivation to the students to make the students excited to follow the lesson that are given.

There are three steps in whilst-activity are exploration, elaboration and confirmation.in exploration, The teacher asks students about the attention of students to follow the lesson today. The teacher gives some questions to the students about the material today. In the elaboration, The teacher explains to the students about definition, generic structure and language feature about descriptive text. Students listen the explanation of teacher. The teacher asks to the students to make a group consists of 4 or 5 students, and then the teacher gives example how determines the characteristics of pictures that distributed by teacher and give examples about how to make descriptive text based on the pictures that given by teacher. Then the teacher gives worksheet to the students, consist of three tasks, task 1 , the students must arrange the picture about how to determine the characteristics of the picture and then make descriptive text about it. Task 2, the students must mention the generic stuctures and language features too. Task 3, one of member group must present their job in front of class without paper and just take a pictures. In confirmation of exploration, the teacher asks the student to present their job in front of the class.

In the post activity, teacher concludes the lesson by asking to the students about the material. Students answer about the teacher question. Teacher asks about student's difficulty by giving some questions to the students. VARK learning style can be increased student ability in writing skill. There are interactions (feedback) between students and teacher in teaching learning process. The students are very enthusiastic in teaching learning process. The applying of VARK learning style in descriptive text to the seventh grade students of SMPN 2 Jiwan in schooling year 2014/2015 is spending much time because there are some preparations media that done by the teacher.

\section{CONCLUSION}

Based on this research, this research can be appropriated to the goal of material by using VARK learning style. The teacher can be applied it well and the students can use VARK learning style in learning writing. The students can be enjoyed with VARK learning style in writing skill. The students can write sentences by using their own words. In other hand, the teacher should give more attention to the the students. So, the students can be learn with happyness. The teacher is expected more creative to choose suitable media and learning style that is used in teaching learning process. Then, the result of the research can be used as the information for English teacher in improving English teaching learning.

\section{REFERENCES}

Anderson, M. (1998). Text types in English. Nationaly Library of Australia: Mcmilan.

Bogdan, R., and Biklen, S.K. (2007). Qualitative Reseach for Education. Syracuse University: Pearson.

Creswell, J. W. (2007). Qualitative Inquiry \& Research Design. United States of America: Sage Publications.

Douglas, B. (2000). Teaching by Principles an Interactive Approach to Language Pedagogy, second edition. San Francisco: Longman

Fleming D, Neil. (2001). Not Another Inventory, Rather a Catalyst for Reflection. New Zealand: University of Nebraska

Harmer, J. (1998). How to Teach Writing. Edinburgh Gate: Longman. 
English Teaching Journal, Vol. 5 No. 1, Juni 2017

ISSN: 2338-2678

Harmer, J. (2004). How to Teach Writing. Edinburgh Gate: Pearson Longman

Hyland, K. (2003). Second language Writing. New York: Cambridge University Press.

Jackson. (2004). Learning Styles and Pedagogy in Post-16 Learning. Trowbridge, Wiltshire: Learning and Skills Research center.

Kothari, C.R. (2004). Methods \&Techniques, Second Edition. New Delhi: New Age International Limited.

Kane, T. (1998). OXFORD essential Guide for Writing. New York: Berkley Books New York.

Miles, M., and Huberman, M. (1994). Qualitative data Analysis. California: Sage Publications.

O'malley, J. M. (1996). Authentic Assessment for English Language Learner. United States of America: Longman

Spring, S. (2001). Perspective on Physician Assistant Education vol 2. Cambridge: Cambridge University Press.

Yin, R. K. (2011). Qualitative Research from Start to Finish. New York: The Guilford Press 